\title{
Life Cycle Cost Analysis and Carbon Credit Earned by Hybrid PV/T Solar Water Heater for Delhi Climatic Conditions
}

\author{
Swapnil Dubey and G.N. Tiwari* \\ Centre for Energy Studies, Indian Institute of Technology Delhi, Hauz Khas, New Delhi 110016, India
}

\begin{abstract}
In this communication, a study has been carried out to evaluate the life cycle cost analysis and carbon credit earned by hybrid PV/T solar water heater. The study has been based on thermal, electrical and exergy output of water heater. The solar water heater is installed at Solar Energy Park, IIT Delhi. The annual energy and exergy gain have been evaluated by considering four types of weather conditions (A, B, C and D Type) of New Delhi and considering a case that the hot water is withdrawal two times in the afternoon and two times in the evening in a day. This paper gives the total carbon credit earned by hybrid PV/T water heater as per norms of Kyoto Protocol for Delhi climatic conditions.

We have found that (i) the cost/kWh is higher in case of exergy when compared with cost $/ \mathrm{kWh}$ on the basis of thermal energy (ii) if this type of system is installed at $10 \%$ of the total residential houses in Delhi then the total carbon credit earned by PV/T water heater annually in terms of thermal energy is Rs. 105.6 cores and in terms of exergy is Rs. 10.2 cores respectively.
\end{abstract}

Keywords: Photovoltaic, exergy, thermal energy, cost analysis, carbon credit, solar collectors.

\section{INTRODUCTION}

The thermal energy has wider applications in the human's life. It can be generally utilized in the form of either low grade (low temperature) or high grade (high temperature). The temperature profiles of the photovoltaic (PV) module in a non-steady state condition with respect to time have studied [1]. The overall electrical efficiency of the PV module can be increased by increasing the packing factor (PF) and reducing the temperature of the PV module by using the thermal energy associated with the PV module [2, 3]. The carrier of thermal energy associated with the PV module may be either air or water. Once thermal energy withdrawal is integrated with the photovoltaic (PV) module, it is referred as hybrid PV/T system.

Photovoltaic-thermal (PV/T) technology refers to the integration of a PV module and conventional solar thermal collector in a single piece of equipment. The rationale behind the hybrid concept is that a solar cell converts solar radiation to electrical energy with peak efficiency in the range of 9$12 \%$, depending on specific solar-cell type and thermal energy through water heating. More than $80 \%$ of the solar radiation falling on photovoltaic (PV) cells is not converted to electricity, but either reflected or converted to thermal energy. In view of this, hybrid photovoltaic and thermal (PV/T) collectors are introduced to simultaneously generate electricity and thermal power [4].

The PV/T water heating system, two types of combipanel (hybrid PV/T) have been considered, namely:

a) The parallel plate configuration [5-8] and

*Address correspondence to these authors at the Centre for Energy Studies, Indian Institute of Technology Delhi, Hauz Khas, New Delhi 110016, India; Tel: +11 26591258; E-mail: gntiwari@ces.iitd.ac.in b) The tube-in-plate configuration [3, 6, 9-12].

Chow [10] has concluded that the tube-in-plate absorber collector with single glazing is regarded as one of the most promising design. He has also concluded that the partial covered flat plate collector by PV module gives better thermal and electrical output from the photovoltaic thermal $(\mathrm{PV} / \mathrm{T})$ water heating system. He has concluded his findings on the basis of indoor simulation.

Zondag et al. [9] developed a model of a hybrid PV/T water collector and performed experimental studies of such systems for varying sizes. Recently Zondag [13] carried out rigorous review on research work of a PV-thermal collector and system, carried out by various scientists till 2006. The relations between energy and exergy, energy and sustainable development, energy policy making, exergy and the environment and exergy in detail are reported by [14]. The annual thermal and exergy efficiency and life cycle analysis of a hybrid $\mathrm{PV} / \mathrm{T}$ air collector for different Indian climate conditions are reported by [15].

Energy consumption of a country is one of the indicators of its socio economic development. Per capita energy consumption in India is also one of the lowest in the world. It is about $30 \%$ of that in China, about $22 \%$ of that in Brazil and about $3.18 \%$ of that in USA. With development the per capita energy consumption is likely to increase. At present our annual economic growth rate is $8-10 \%$, per annum. For energy India depends on oil and gas imports, which account for over $65 \%$ of its consumption; it is likely to increase further considering the economic development, rise in living condition of people and rising prices. Coal, which currently accounts for over $60 \%$ of India's electricity production, is the major source of emission of greenhouse gases and that of acid rains. In the business-as-usual scenario, India will ex- 
haust its oil reserves in 22 years, its gas reserves in 30 years and its coal reserves in 80 years [16]. More alarming, the coal reserves might disappear in less than 40 years if India continues to grow at $8 \%$ a year [16].

Carbon Credit Trading (Emission Trading) is an administrative approach used to control pollution by providing economic incentives for achieving reductions in the emissions of pollutants. A credit gives the owner the right to emit one ton of carbon dioxide. International treaties such as the Kyoto Protocol set quotas on the amount of greenhouse gases countries can produce. There are currently two exchanges for brought and sold of carbon credits: the Chicago Climate Exchange and the European Climate Exchange. European and Japanese Companies were the major buyers and China was the major seller of the carbon credits in 2005-06. Present market rate is fluctuating at $€ 20$ 22 in the European Climate Exchange [17].

\section{EXPERIMENTAL SET UP AND OBSERVATIONS}

In water heating system two flat plate collectors are connected in series. Specifications of flat plate collector are given in Table 1. The whole absorber and glass cover is encased in an aluminum metallic box with $0.1 \mathrm{~m}$ glass wool insulation below the absorber to reduce bottom losses. The photograph of the system is shown in Fig. (1).

Table 1. Dimensions of Photovoltaic Thermal (PV/T) Solar Water Heating System

\begin{tabular}{|c|c|c|}
\hline S No. & Components & Specifications \\
\hline \hline 1. & Capacity of Storage Tank & 200 Liters \\
\hline 2. & Collectors & Flat Plate, Tube in plate Type \\
\hline 3. & Area of Collector & $2.16 \mathrm{~m}^{2}$ \\
\hline 4. & Tube Diameter & $0.0125 \mathrm{~m}$ \\
\hline 5. & Tube Material & Copper Tubes \\
\hline 6. & Plate Thickness & $0.002 \mathrm{~m}$ \\
\hline 7. & Air Gap & $0.01 \mathrm{~m}$ \\
\hline 8. & Thickness of Insulation & $0.1 \mathrm{~m}$ \\
\hline 9. & Thickness of Glass & $0.004 \mathrm{~m}$ \\
\hline 10. & Angle of Collector & $30^{\circ}$ \\
\hline 11. & PV Module & Glass to Glass Type \\
\hline 12. & Area of Module & $0.66 \mathrm{~m}^{2}$ \\
\hline 13. & Area of Solar Cell & $0.015 \mathrm{~m}^{2}$ \\
\hline 14. & Total Area of Solar Cell & $0.54 \mathrm{~m}^{2}$ \\
\hline 15. & Non Packing Area & $0.12 \mathrm{~m}^{2}$ \\
\hline 16. & No. of Solar Cells & 36 \\
\hline 17. & PV Module & $75 \mathrm{~W}^{2}, 60 \mathrm{~W}, 2800 \mathrm{RPM}$ \\
\hline 18. & DC Motor & \\
\hline
\end{tabular}

A glass to glass photovoltaic (PV) module with an effective area of $0.66 \mathrm{~m}^{2}$ is integrated at the bottom of one of the collector. In this case, solar radiation is transmitted through non-packing area of PV module and finally absorbed by the blackened absorber. Further, the thermal energy associated with PV module is transferred to absorber by convection for further heating of absorber. Water below absorber gets heated and moves in the upward direction. The outlet of water at the end of absorber which is covered with PV module ( $\mathrm{T}_{\mathrm{fol}}$, Fig. (2)) becomes inlet to glass-absorber combination. Such collector is referred a photovoltaic/thermal (PV/T) water collector.

The outlet of photovoltaic/thermal (PV/T) water collector $\left(\mathrm{T}_{\mathrm{fo} 2}\right)$ is further connected to the inlet of conventional flat plate collector for higher operation temperature shown in Fig. (2). Both collectors are connected to an insulated storage tank of capacity 200 liters. There is a provision of a DC water pump (18V, 60W, 2800RPM) connected to PV module to circulate the water between collectors and storage tank in a forced mode.

Performance of the hybrid PV/T water heater is evaluated by considering four types of weather conditions of New Delhi, are defined as:

Type A: The ratio of daily diffuse to daily global radiation is less than or equal to 0.25 and sunshine hours greater then or equal to 9 hours.

Type B: The ratio of daily diffuse to daily global radiation between 0.25 to 0.50 and sunshine hours between 7 to 9 hours.

Type C: The ratio of daily diffuse to daily global radiation between 0.50 to 0.75 and sunshine hours between 5 to 7 hours.

Type D: The ratio of daily diffuse to daily global radiation is greater than or equal to 0.75 and sunshine hours less then or equal to 5 hours.

The temperatures at inlet, outlet, water in storage tank and solar radiations are measured by data logger systems on minute basis.

\section{THERMAL MODELING}

In order to write the energy balance equation the following assumptions have been made:

- The heat capacity of photovoltaic/thermal (PV/T) collector has been neglected in comparison with the heat capacity of water in the storage tank.

- There is no temperature stratification in the water of the storage tank due to forced mode of operation.

- One dimension heat conduction is good approximation for the present study.

- The system is in quasi-steady state.

- The ohmic losses in the solar cell are negligible.

The energy balance equations for each component of $(\mathrm{PV} / \mathrm{T})$ solar water heating system are as follows:

\section{(i) For Solar Cells of PV Module (Glass-Glass)}

$\alpha_{c} \tau_{c} \beta_{c} I(t) W d x=\left[U_{t c, a}\left(T_{c}-T_{a}\right)+h_{c, p}\left(T_{c}-T_{p}\right)\right] W d x+\tau_{c} \eta_{c} \beta_{c} I(t) \cdot W d x$ 


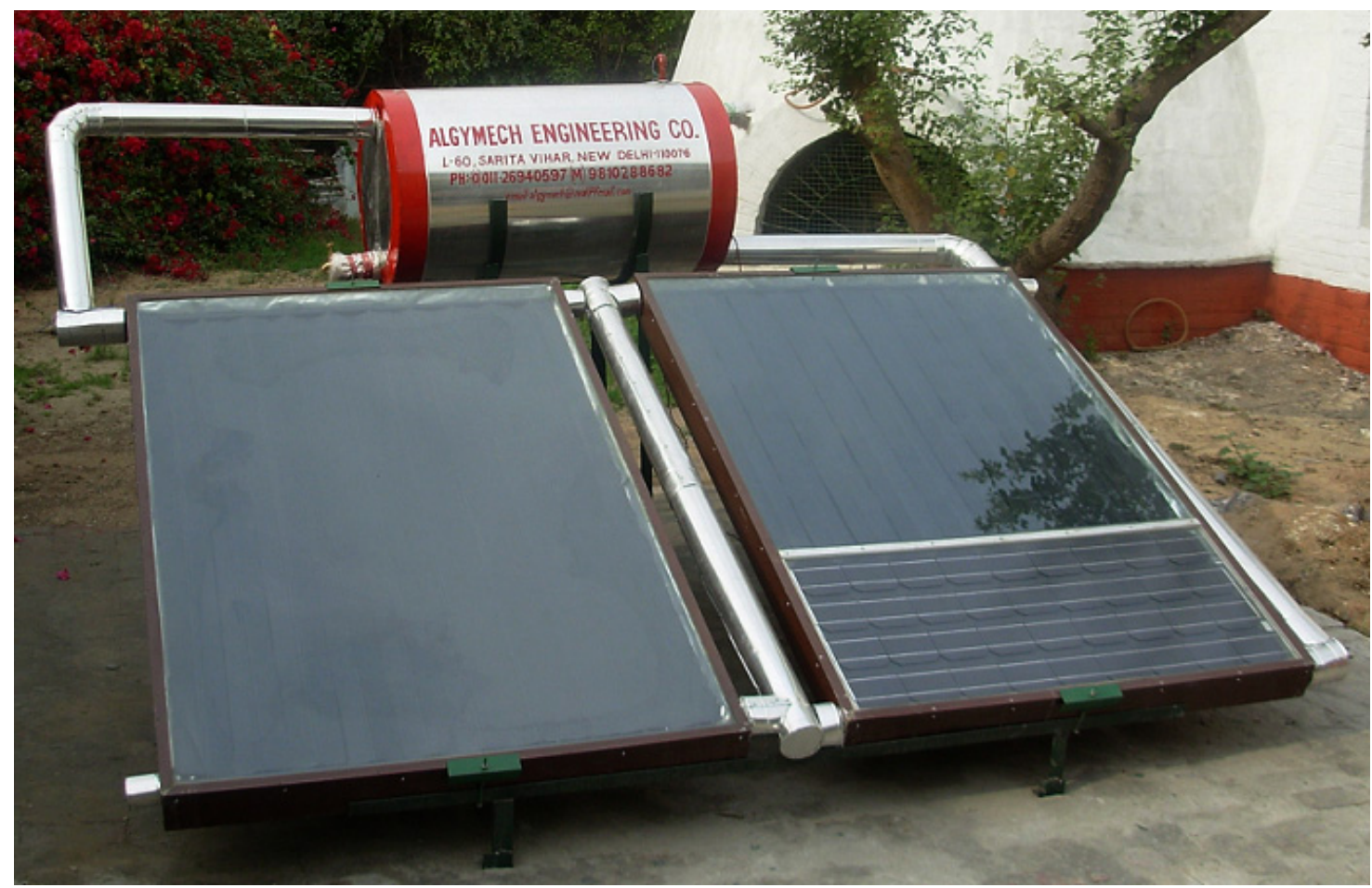

Fig. (1). Photograph of a combined photovoltaic thermal (PV/T) glass to glass solar water heating system.

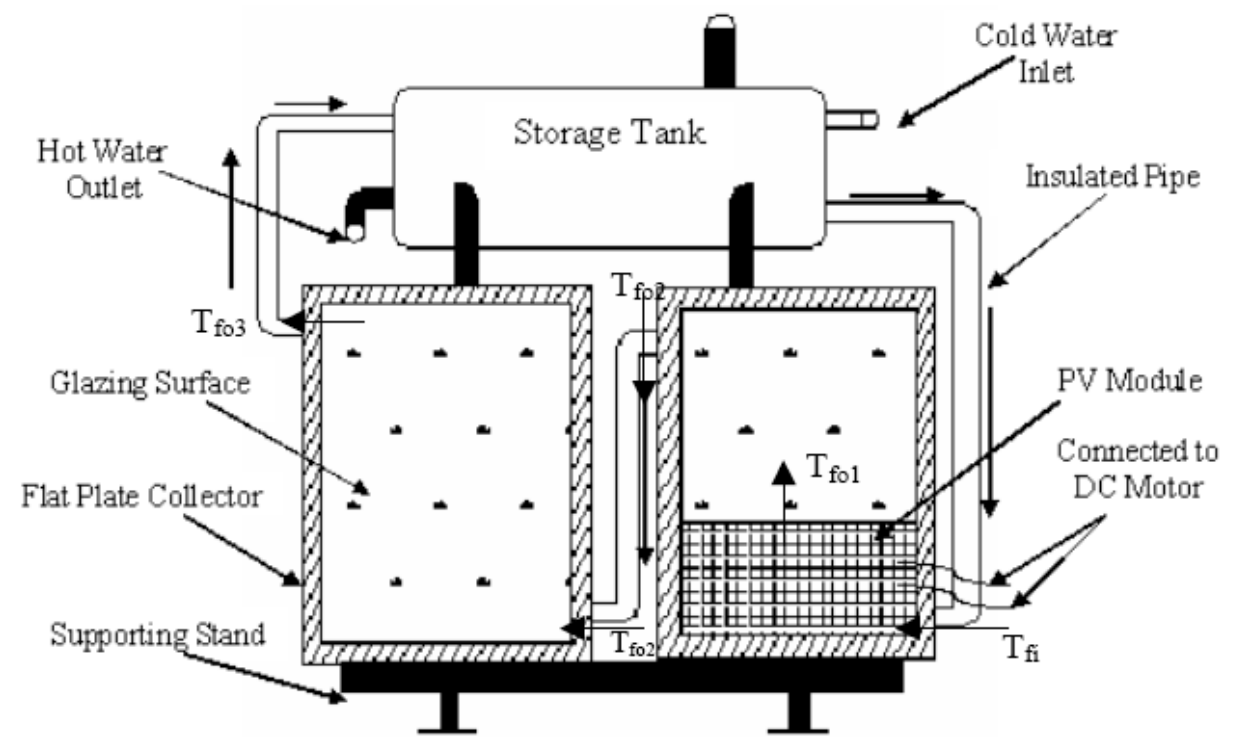

Fig. (2). Cross sectional view of a combined photovoltaic thermal (PV/T) solar water heating system.

(ii) For Blackened Absorber Plate Temperature Below the PV Module (Glass-Glass)

$\alpha_{p}\left(1-\beta_{c}\right) \tau_{g}^{2} I(t)+h_{c, p}\left(T_{c}-T_{p}\right)=h_{p, f}\left(T_{p}-T_{f}\right)$

(iii) For Water Flowing Through an Absorber Pipe Below the PV Module (Glass-Glass)

The energy balance of flowing water through absorber pipe is given by,

$\dot{m}_{f} C_{f} \frac{d T_{f}}{d x} d x=F^{\prime} h_{p, f}\left(T_{p}-T_{f}\right) W d x$
The rate of thermal energy available at the end of absorber PV module (glass-glass) is evaluated as,

$\dot{Q}_{u, m}=A_{m} F_{R m}\left(P F_{2}(\alpha \tau)_{m, e f f} I(t)-U_{L, m}\left(T_{f i}-T_{a}\right)\right)$

(iv) The Rate of Thermal Energy Available at the End of First Collector

Following Duffie and Beckman [18] and Tiwari [19], the rate of thermal energy available from the first flat plate collector can be evaluated as,

$\dot{Q}_{u, c 1}=A_{c 1} F_{R c 1}\left((\alpha \tau)_{c 1, e f f} I(t)-U_{L, c 1}\left(T_{f o 1}-T_{a}\right)\right)$ 
Here, $T_{f o 1}=T_{f i}+\frac{\dot{Q}_{u, m}}{\dot{m}_{f} C_{f}}$

(v) The Rate of Thermal Energy Available at the End of Second Collector

An expression for the rate of thermal energy available at the end of second collector will be as follows;

$\dot{Q}_{u(m+c 1+c 2)}=\dot{m}_{f} C_{f}\left(T_{f o 3}-T_{f i}\right)$

$\dot{Q}_{u, c 2}=A_{c 2} F_{R c 2}\left((\alpha \tau)_{c 2, e f f} I(t)-U_{L, c 2}\left(T_{f o 2}-T_{a}\right)\right)$

Here, $T_{f o 2}=T_{f i}+\frac{\dot{Q}_{u, m}}{\dot{m}_{f} C_{f}}+\frac{\dot{Q}_{u, c 1}}{\dot{m}_{f} C_{f}}$

On solving the Eqs. (4), (5) and (6) we get,

$\begin{aligned} \dot{Q}_{u(m+c 1+c 2)} & =\left[\begin{array}{l}A_{m} F_{R m} P F_{2}(\alpha \tau)_{m, e f f}\left(1-K_{1}\right)+ \\ A_{c 1} F_{R c 1}(\alpha \tau)_{c 1, e f f}\left(1-K_{2}\right)+ \\ A_{c 2} F_{R c 2}(\alpha \tau)_{c 2, e f f}\end{array}\right] I(t) \\ & -\left[\begin{array}{l}A_{m} F_{R m} U_{L, m}\left(1-K_{1}\right)+ \\ A_{c 1} F_{R c 1} U_{L, c 1}\left(1-K_{2}\right)+ \\ A_{c 2} F_{R c 2} U_{L, c 2}\end{array}\right]\left(T_{f i 1}-T_{a}\right)\end{aligned}$

where, $K_{1}=\left[\begin{array}{l}\frac{A_{c 1} F_{R c 1} U_{L, c 1}}{\dot{m}_{f} C_{f}}+\frac{A_{c 2} F_{R c 2} U_{L, c 2}}{\dot{m}_{f} C_{f}}- \\ \frac{A_{c 1} F_{R c 1} U_{L, c 1} A_{c 2} F_{R c 2} U_{L, c 2}}{\left(\dot{m}_{f} C_{f}\right)^{2}}\end{array}\right]$

and $K_{2}=\left[\frac{A_{c 2} F_{R c 2} U_{L, c 2}}{\dot{m}_{f} C_{f}}\right]$

\section{(vi) Energy Balance for Complete Water Heating System}

The rate of thermal energy available at the outlet of second collector is fed into insulated storage tank, and then the energy balance of whole system will be,

$\dot{Q}_{u,(m+c 1+c 2)}=M_{w} C_{w} \frac{d T_{w}}{d t}+(U A)_{t k}\left(T_{w}-T_{a}\right)$

The above equation can be solved by assuming $\mathrm{T}_{\mathrm{fi}}=\mathrm{T}_{\mathrm{w}}$ due to perfectly insulating connecting pipes. Using Eq. (7) the tank water temperature can be obtained by as,

$$
\begin{aligned}
& (\alpha \tau)_{e f f} I(t)-(U A)_{e f f}\left(T_{w}-T_{a}\right)=M_{w} C_{w} \frac{d T_{w}}{d t}+ \\
& (U A)_{t k}\left(T_{w}-T_{a}\right)+\dot{m}_{w} C_{w}\left(T_{w}-T_{a}\right) \\
& \text { or, } \frac{d T_{w}}{d t}+a T_{w}=f(t)
\end{aligned}
$$

where, $a=\frac{\left[(U A)_{e f f}+(U A)_{t k}+\dot{m}_{w} C_{w}\right]}{M_{w} C_{w}}$

and $f(t)=\frac{(\alpha \tau)_{e f f} I(t)+\left[(U A)_{e f f}+(U A)_{t k}+\dot{m}_{w} C_{w}\right] T_{a}}{M_{w} C_{w}}$

On solving the above differential equation the expression for tank water temperature can be obtained as,

$T_{w}=\frac{f(t)}{a}\left(1-e^{-a t}\right)+T_{w 0} e^{-a t}$

\section{(vii) Energy Analysis}

The energy analysis is based on the first law of thermodynamics, and the expression for total thermal gain can be defined as,

$$
\sum \dot{Q}_{u, \text { total }}=\sum \dot{Q}_{u, \text { thermal }}+\frac{\sum \dot{Q}_{u, \text { electrical }}}{0.38}
$$

Overall thermal output from a $\mathrm{PV} / \mathrm{T}$ system $=$ thermal energy collected by the PV/T system + (Electrical output $/$ çpower) where, çpower is the electric power generation efficiency for a conventional power plant.

This is so because electrical energy is a high-grade form of energy which is required for operation of DC motor. This electrical energy has been converted to equivalent thermal by using electric power generation efficiency as 0.38 for a conventional power plant [6].

In the case of withdrawal from tank the thermal energy output from the tank can be written as,

$$
\dot{Q}_{u, \text { thermal }}=\dot{m}_{w} C_{w}\left(T_{w}-T_{a}\right)
$$

\section{(viii) Exergy Analysis}

The exergy analysis is based on the second law of thermodynamics, which includes accounting the total exergy inflow, exergy outflow and exergy destructed from the system. as,

The general exergy balance for a collector can be written

$$
\begin{aligned}
& \sum \dot{E} x_{\text {in }}-\sum \dot{E} x_{\text {out }}=\sum \dot{E} x_{\text {dest }} \\
& \text { or, } \sum \dot{E} x_{\text {in }}-\sum\left(\dot{E} x_{\text {thermal }}+\dot{E} x_{\text {electrical }}\right)=\sum \dot{E} x_{\text {dest }}
\end{aligned}
$$

where,

$$
\begin{aligned}
& \dot{E} x_{\text {in }}=A_{c} \times N_{c} \times I(t) \times\left[1-\frac{4}{3} \times\left(\frac{T_{a}}{T_{s}}\right)+\frac{1}{3} \times\left(\frac{T_{a}}{T_{s}}\right)^{4}\right] \\
& \dot{E} x_{\text {thermal }}=\dot{Q}_{u}\left[1-\frac{T_{a}+273}{T_{f o}+273}\right] \text { and } \\
& \dot{E} x_{\text {electrical }}=\eta_{c} \times A_{c} \times N_{c} \times I(t)
\end{aligned}
$$


where, $A_{c}$ is area of collector and $T_{s}$ is the Sun temperature in Kelvin.

In addition to the above equations the relations used for defining the design parameters and the values of design parameters are shown in appendix I and Table 2 respectively.

Table 2. Design Parameters of Photovoltaic Thermal (PV/T) Collector and Storage Tank

\begin{tabular}{|c|c|}
\hline Parameters & Values \\
\hline \hline $\mathrm{A}_{\mathrm{Cl}}$ & $2.16 \mathrm{~m}^{2}$ \\
$\mathrm{~A}_{\mathrm{C} 2}$ & $1.5 \mathrm{~m}^{2}$ \\
$\mathrm{~A}_{\mathrm{m}}$ & $0.66 \mathrm{~m}^{2}$ \\
$\mathrm{C}_{\mathrm{f}}$ & $4190 \mathrm{~J} / \mathrm{kg} \mathrm{K}$ \\
$\mathrm{D}$ & $0.0125 \mathrm{~m}$ \\
$\mathrm{~F}^{\prime}$ & 0.968 \\
$\mathrm{~F}_{\mathrm{Rc} 1}$ & 0.95 \\
$\mathrm{~F}_{\mathrm{Rc} 2}$ & 0.94 \\
$\mathrm{~F}_{\mathrm{Rm}}$ & 0.96 \\
$\mathrm{~h}$ & $1000 \mathrm{~W} / \mathrm{m}^{2}$ \\
$\mathrm{~h}_{\mathrm{c}, \mathrm{p}}$ & $5.7 \mathrm{~W} / \mathrm{m}^{2}$ \\
$\mathrm{~h}_{\mathrm{p}, \mathrm{f}}$ & $100 \mathrm{~W} / \mathrm{m}^{2}$ \\
$\mathrm{PF}_{1}$ & 0.375 \\
$\mathrm{PF}_{2}$ & 0.965 \\
$\mathrm{~K}$ & $204 \mathrm{~W} / \mathrm{m} \mathrm{K}^{2}$ \\
$\dot{m}$ & $0.06 \mathrm{~kg} / \mathrm{sec}$ \\
$\mathrm{M}_{\mathrm{w}}$ & $200 \mathrm{~kg}$ \\
$\mathrm{U}_{\mathrm{L}}$ & $6 \mathrm{~W} / \mathrm{m}^{2}$ \\
$\mathrm{U}_{\mathrm{L} 1}$ & $3.56 \mathrm{~W} / \mathrm{m}^{2} \mathrm{~K}$ \\
$\mathrm{U}_{\mathrm{LCl}}$ & $6 \mathrm{~W} / \mathrm{m}^{2}$ \\
$\mathrm{U}_{\mathrm{LC} 2}$ & $6 \mathrm{~W} / \mathrm{m}^{2}$ \\
$\mathrm{U}_{\mathrm{Lm}}$ & $3.44 \mathrm{~W} / \mathrm{m}^{2} \mathrm{~K}$ \\
$\mathrm{U}_{\mathrm{tc}, \mathrm{a}}$ & $9.5 \mathrm{~W} / \mathrm{m}^{2} \mathrm{~K}$ \\
$\left(\mathrm{UA}_{\mathrm{tk}}\right.$ & $4.38 \mathrm{~W} / \mathrm{K}$ \\
$\mathrm{V}$ & $1 \mathrm{~m} / \mathrm{s}$ \\
$\mathrm{W}$ & $0.125 \mathrm{~m}$ \\
$\alpha_{\mathrm{g}}$ & 0.9 \\
$\tau_{\mathrm{c}}$ & 0.95 \\
$\beta_{\mathrm{c}}$ & 0.83 \\
$\eta_{\mathrm{c}}$ & 0.12 \\
$\alpha_{\mathrm{p}}$ & 0.8 \\
\hline $\mathrm{V}$ & 0.95 \\
\hline & \\
\hline
\end{tabular}

4. LIFE CYCLE COST ANALYSIS AND ENERGY METRICS

\section{(i) Embodied Energy Consumption}

Embodied energy analysis shows the total energy consumed in manufacturing of the product. It includes material production energy, the transportation energy, the solar cell /module fabrication energy, the human energy, installation energy, maintenance energy and the finally disposal/salvage energy. The detailed list of embodied energy is given in Table 3 .

\section{(ii) Energy Payback Time (EPBT)}

Energy payback time is the ratio of the total energy consumed in production and installation of the system $\left(E_{i n}\right)$ to the total energy out $\left(E_{\text {out }}\right)$.

$$
T_{\text {epb }}=\frac{E_{\text {in }}}{E_{\text {out }}}
$$

\section{(iii) Energy Production Factor (EPF)}

It is used to predict the overall performance of the system. This is defined as the ratio of the output energy and the input energy which predicts the overall performance of the system. Energy production factor is defined by two types

(i) On annual basis, and

$\chi_{a}=\frac{E_{\text {out }}}{E_{\text {in }}}$

or, $\chi_{a}=\frac{1}{T_{e p b}}$

If $\chi_{\mathrm{a}} \rightarrow 1$, for $\mathrm{T}_{\mathrm{epb}}=1$ the system is worthwhile otherwise it is not worth from energy point of view.

(ii) On life time basis.

$\chi_{L}=\frac{E_{\text {out }} \times T}{E_{\text {in }}}$

\section{(iv) Life Cycle Conversion Efficiency (LCCE)}

This is the net energy productivity of the system with respect to the solar input (radiation) over the life time of the system, ( $\mathrm{T}$ years) given by

$$
\phi(t)=\frac{E_{o u t} \times T-E_{\text {in }}}{E_{\text {sol }} \times T}
$$

\section{(v) Annualized Uniform Cost (Unacost)}

Annualized uniform cost is defined as a product of present value of the system and capital recovery factor (CRF) [19].

Unacost $=$ Net present value $\times$ Capital recovery factor

$$
C R F=\frac{i(i+1)^{n}}{(i+1)^{n}-1}
$$

here, $n=$ no. of years and $i=$ interest rate per year.

Let $P$ is present value and $R_{1}, R_{2}, \ldots . . R_{n}$ is operational, maintenance and pump replacement cost per year and $R_{3,1}$, $R_{6,2}, \ldots . . R_{n, n}$ is black painting, cleaning and glass replacement cost in every three year. Then the net present value is evaluated as,

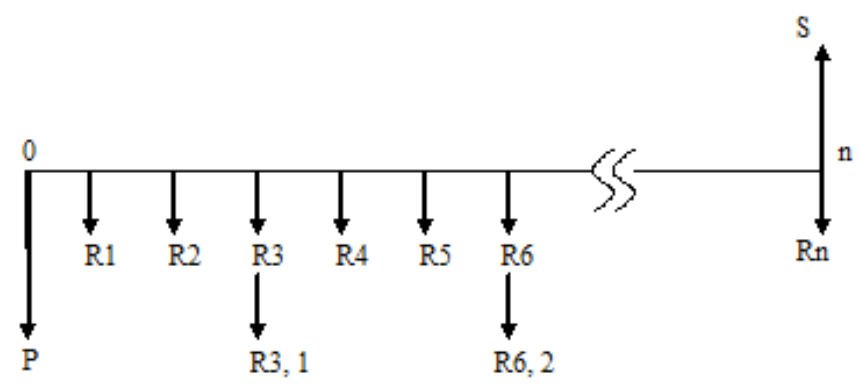


Table 3. Break up of Embodied Energy of Different Components of Fabrication of Hybrid (PV/T) Solar Water Heater

\begin{tabular}{|c|c|c|c|c|c|c|}
\hline \multirow{2}{*}{ Components } & \multirow{2}{*}{ Items } & \multirow{2}{*}{ Quantity } & \multirow{2}{*}{ Total Weight (kg) } & \multirow{2}{*}{ Embodied Energy (MJ/kg) } & \multicolumn{2}{|c|}{ Total Embodied Energy } \\
\hline & & & & & MJ & kWh \\
\hline \multirow{5}{*}{ Storage tank } & Storage tank & 1 & 18.0 & 36.1 & 649.8 & 180.5 \\
\hline & Glass wool & $23 \mathrm{~m}^{2}$ & $0.1 \mathrm{~m}^{3}$ & $139 \mathrm{MJ} / \mathrm{m}^{3}$ & 13.9 & 3.86 \\
\hline & $\mathrm{Al}$ sheet & 1 & 1.2 & 170 & 204 & 56.7 \\
\hline & Mild steel stand & 1 & 14 & 34.2 & 478.8 & 132.7 \\
\hline & Brass water tap & 1 & 0.2 & 62.7 & 12.54 & 3.48 \\
\hline \multirow{15}{*}{$\begin{array}{l}\text { Flat plate } \\
\text { Collector } \\
\text { Quantity } 2\end{array}$} & Copper riser $1 / 2^{\prime \prime}$ & $20 \times 1.8=36 \mathrm{~m}$ & 8.2 & 81.0 & 664.2 & 184.5 \\
\hline & Header $1^{\prime \prime}$ & $4 \times 1.15=4.6 \mathrm{~m}$ & 3.8 & 81.0 & 307.8 & 85.5 \\
\hline & Al box & 2 & 10 & 199.0 & 1990.0 & 552.0 \\
\hline & $\mathrm{Cu}$ sheet & 2 & 11 & 132.7 & 1460 & 405.6 \\
\hline & Glass cover toughened $4 \mathrm{~mm}$ & $2\left(3.75 \mathrm{~m}^{2}\right)$ & $0.01464 \mathrm{~m}^{3}$ & $66020 \mathrm{MJ} / \mathrm{m}^{3}$ & 966.5 & 268.3 \\
\hline & Glass wool & $13 \mathrm{~m}^{2}$ & $0.064 \mathrm{~m}^{3}$ & $139 \mathrm{MJ} / \mathrm{m}^{3}$ & 8.89 & 2.5 \\
\hline & Nuts / bolts/screws & 32 & 1 & 31.06 & 31.06 & 8.6 \\
\hline & Union /elbow & 8 & 1.5 & 46.8 & 70.2 & 19.5 \\
\hline & Nozzle/flange & 8 & 1 & 62.1 & 62.1 & 17.3 \\
\hline & Mild steel stand & 1 & 40 & 34.2 & 1368 & 380 \\
\hline & paint & $1 \mathrm{~L}$ & $1 \mathrm{~L}$ & 90.4 & 90.4 & 25.1 \\
\hline & Rubber gasket & $18 \mathrm{~m}$ & 4.2 & 11.83 & 49.7 & 13.8 \\
\hline & G I pipes $1 / 2^{\prime \prime}$ & & 9.5 & 44.1 & 418.9 & 116.4 \\
\hline & Al frame $1^{\prime \prime}$ & $12 \mathrm{~m}$ & 2.5 & 170 & 425 & 118 \\
\hline & Al sheet 24 gauge & & 2.5 & 170 & 425 & 118 \\
\hline \multirow{2}{*}{ PV module } & Glass to glass & 1 & $0.66 \mathrm{~m}^{2}$ & $3528 / \mathrm{m}^{2}$ & 2328.5 & 646.8 \\
\hline & BOS & & & 720.0 & 720.0 & 200 \\
\hline \multirow{10}{*}{ Water pump } & Copper wire & & 0.150 & 110.19 & 16.5 & 4.6 \\
\hline & Copper commuter & 2 & 0.04 & 70.6 & 2.8 & 0.78 \\
\hline & Si-steel armature & 1 & 0.05 & $*$ & $*$ & $*$ \\
\hline & Wire insulation & 2 & 0.01 & $*$ & $*$ & $*$ \\
\hline & Motor body(SS) & 1 & 0.100 & 36.1 & 3.61 & 1.0 \\
\hline & Casing (brass) & 1 & 0.300 & 62.0 & 18.6 & 5.2 \\
\hline & bearings & 2 & 0.030 & $*$ & $*$ & $*$ \\
\hline & Steel shaft & 1 & 0.050 & 12.5 & 0.625 & 0.17 \\
\hline & Impellers(plastic) & 1 & $*$ & $*$ & $*$ & $*$ \\
\hline & Nuts/screws/flange & & 0.100 & 31.06 & 3.1 & 0.86 \\
\hline Total & & & & & 12790.63 & 3552.95 \\
\hline
\end{tabular}

\section{Net $\operatorname{Pr}$ esent Value $=$}

$$
\begin{aligned}
& P+R_{1} \times\left[\frac{(i+1)^{n}-1}{i(i+1)^{n}}\right]_{i, n}+R_{3,1} \times\left[\frac{1}{(i+1)^{n}}\right]_{i, 3} \\
& +R_{6,2} \times\left[\frac{1}{(i+1)^{n}}\right]_{i, 6} \\
& +R_{9,3} \times\left[\frac{1}{(i+1)^{n}}\right]_{i, 9}+\ldots \ldots \ldots \ldots \ldots . . . . . . . . .\left[\frac{1}{(i+1)^{n}}\right]_{i, n}
\end{aligned}
$$

\section{RESULT AND DISCUSSION}

Eq. (9) and (10b) have been computed using MATLAB software for evaluating the thermal energy gain from the tank by considering the A, B, C and D type conditions and Eq. (10a) has been used for calculating the monthly thermal energy gain. The electrical energy is converted into thermal energy and the variation of total thermal energy gain is shown in Fig. (3). Figure shows that the overall annual gain is $2720.1 \mathrm{kWh}$, however the maximum gain is obtained in May month and minimum is obtained in December month due to the availability of solar radiation. The variation in gain of different weather conditions (A. B, C and D Type) for a month depends upon the number of days belongs to that 


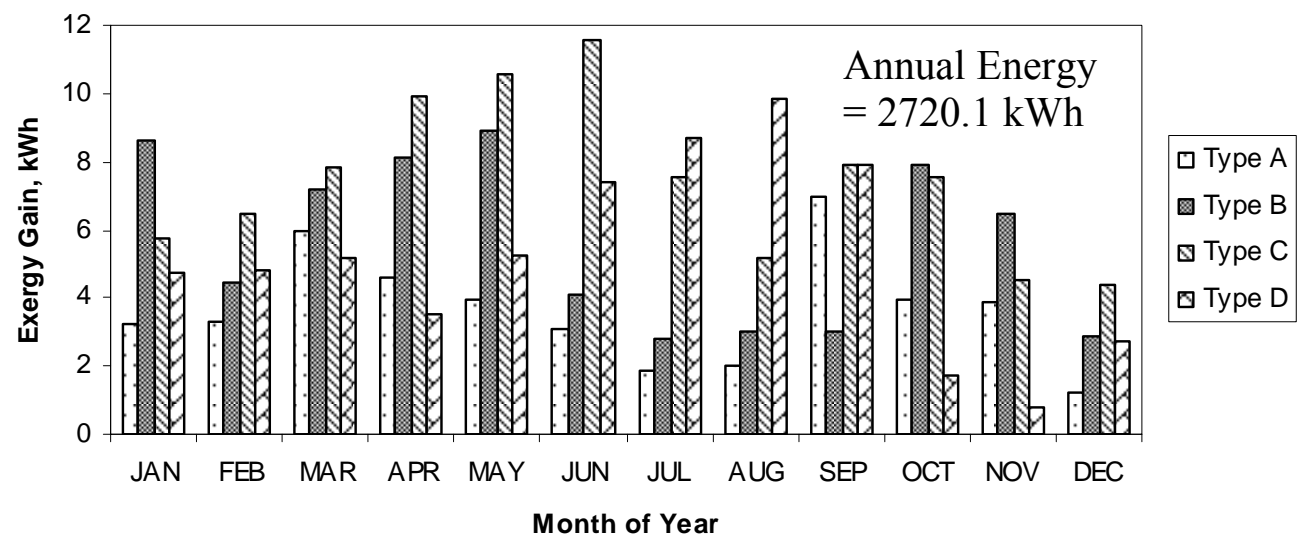

Fig. (3). Monthly variation of thermal energy gain in kWh.

type. Similarly Eq. (11) has been computed for evaluating the monthly exergy gain, sum of electrical energy and thermal exergy. The overall annual exergy gain is $263.3 \mathrm{kWh}$, which is shown in Fig. (4). The monthly variation of overall energy and exergy gain are shown in Table 4.
Eq. (12), (13a,b), (14) and (15) have been used for evaluating the Energy payback time (EPBT), Energy production factor (EPF), Life cycle conversion efficiency (LCCE) and Annualized uniform cost of the system in terms of thermal energy and exergy. The capital cost (P) and salvage value (S) of hybrid $(\mathrm{PV} / \mathrm{T})$ solar water heater are shown in Table 5.

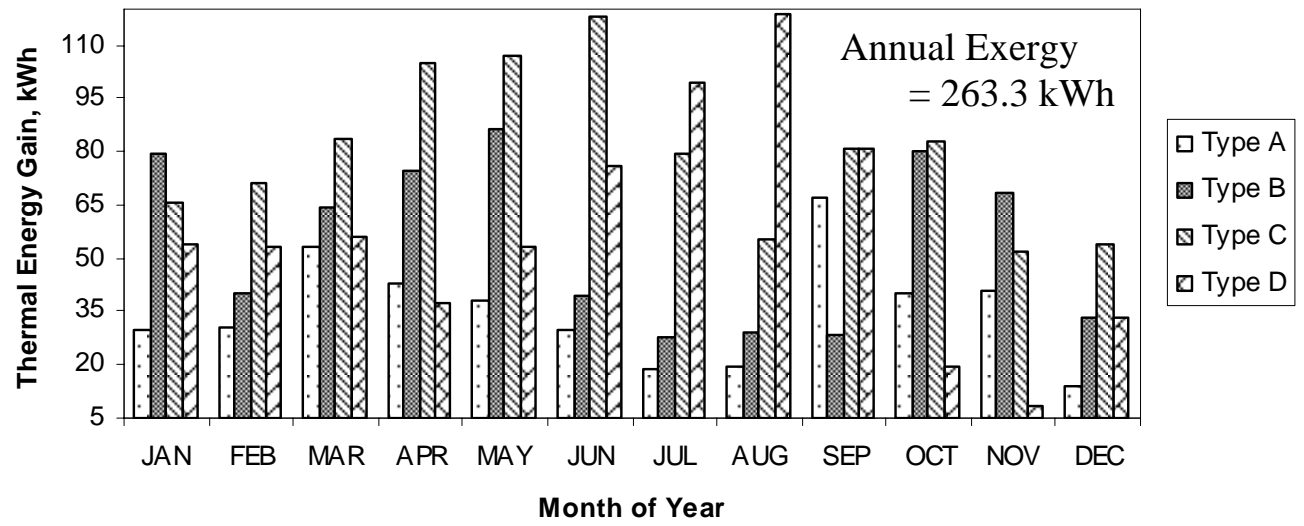

Fig. (4). Monthly variation of exergy gain in $\mathrm{kWh}$.

Table 4. Monthly Variation of Overall Energy and Exergy Gain

\begin{tabular}{|c|c|c|c|c|c|c|}
\hline Month & Thermal Energy & Electrical Energy & Thermal Exergy & Overall Exergy & Thermal Eq. $=($ Ele $/ 0.38)$ & Overall Thermal Energy \\
\hline January & 195.5 & 12.76 & 9.63 & 22.39 & 33.58 & 229.08 \\
\hline February & 165.2 & 11.28 & 7.77 & 19.05 & 29.70 & 194.90 \\
\hline March & 218.1 & 14.69 & 11.49 & 26.18 & 38.66 & 256.76 \\
\hline April & 221.7 & 14.44 & 11.78 & 26.22 & 38.01 & 259.71 \\
\hline May & 243.4 & 15.67 & 13.0 & 28.67 & 41.24 & 284.64 \\
\hline June & 225.1 & 14.51 & 11.71 & 26.22 & 38.19 & 263.29 \\
\hline Jully & 192.8 & 12.28 & 8.6 & 20.88 & 32.32 & 225.12 \\
\hline August & 191.7 & 11.64 & 8.3 & 19.94 & 30.64 & 222.34 \\
\hline September & 220.0 & 14.23 & 11.5 & 25.73 & 37.43 & 257.43 \\
\hline October & 188.4 & 12.84 & 8.31 & 21.15 & 33.80 & 222.20 \\
\hline November & 143.2 & 10.11 & 5.54 & 15.65 & 26.60 & 169.80 \\
\hline December & 113.5 & 8.10 & 3.09 & 11.19 & 21.32 & 134.82 \\
\hline Total & 2318.6 & 152.57 & 110.72 & 263.29 & 401.5 & 2720.1 \\
\hline
\end{tabular}


Table 5. Capital Cost $\left(P_{s}\right)$, Salvage Value $\left(S_{s}\right)$ and Maintenance Cost $\left(M_{s}\right)$ of Hybrid (PV/T) Solar Water Heater

\begin{tabular}{|c|c|c|c|c|c|}
\hline \multirow[b]{2}{*}{ Components } & \multirow[b]{2}{*}{$\begin{array}{l}\text { Qty in } \\
\text { kg }\end{array}$} & \multirow{2}{*}{$\begin{array}{c}\begin{array}{c}\text { Hybrid (PV/T) } \\
\text { Solar Water } \\
\text { Heater }\end{array} \\
\text { Rs.. }\end{array}$} & \multicolumn{3}{|c|}{$\begin{array}{l}\text { Salvage Value of Different Components }\left(S_{\mathrm{S}}\right) \text { at the Inflation Rate of } 4 \% \text { (Present } \\
\text { Values of Scrap for, Iron @ Rs15/kg, Aluminum@Rs80/kg and Copper@Rs250/kg) }\end{array}$} \\
\hline & & & $\begin{array}{l}\text { After } 10 \text { Year } \\
\text { Iron Scrap@ Rs. 22/kg } \\
\text { Aluminum@ Rs. 118/kg } \\
\text { Copper@ Rs. 370/kg }\end{array}$ & $\begin{array}{l}\text { After } 20 \text { Year } \\
\text { Iron Scrap@ Rs. 33/kg } \\
\text { Aluminum@ Rs. 175/kg } \\
\text { Copper@ Rs. 548/kg }\end{array}$ & $\begin{array}{l}\text { After } 30 \text { Year } \\
\text { Iron Scrap@ Rs. 49/kg } \\
\text { Aluminum@ Rs. 259/kg } \\
\text { Copper@ Rs. 811/kg }\end{array}$ \\
\hline Storage tank@Rs.90/kg & 18 & 1620 & 2124 & 3150 & 4662 \\
\hline Glasswool@Rs.60/m² & $0.1 \mathrm{~m}^{3}$ & 1320 & $*$ & $*$ & $*$ \\
\hline Al sheet @ Rs. 165/kg & 1.2 & 198 & 142 & 210 & 311 \\
\hline Mild steel stand & 14 & 700 & 308 & 462 & 686 \\
\hline Total cost of tank & & 3838 & 2574 & 3822 & 5659 \\
\hline \multicolumn{6}{|l|}{ Flat plate collectors (2) } \\
\hline Copper riser@ Rs. 380/kg & 8.2 & 3116 & 3034 & 4496 & 6650 \\
\hline Cu Header @ Rs. 380/kg & 3.8 & 1440 & 1406 & 2082 & 3081 \\
\hline Al sheet @ Rs. 165/kg & 12 & 2160 & 1416 & 2100 & 3108 \\
\hline $\mathrm{Al}$ angle $1 " 12 \mathrm{~m}$ & 2.5 & 450 & 295 & 437 & 647 \\
\hline Cu sheet@ Rs.360/kg & 11 & 4070 & 4070 & 6028 & 8921 \\
\hline Toughened glass $4 \mathrm{~mm}$ & $3.75 \mathrm{~m}^{2}$ & 4340 & $*$ & $*$ & $*$ \\
\hline Glasswool@ Rs.60/m² & $0.064 \mathrm{~m}^{3}$ & 840 & $*$ & $*$ & $*$ \\
\hline G.I. pipes $1 / 2$ & 9.3 & 500 & 205 & 307 & 456 \\
\hline Mild steel stand & 40 & 2000 & 880 & 1320 & 1960 \\
\hline G.I. elbow/union & 1.5 & 300 & 33 & 50 & 75 \\
\hline Nozzle/flange & 1 & 200 & 22 & 33 & 49 \\
\hline Total cost of FPC & & 19416 & 11361 & 16851 & 24872 \\
\hline PV module & $*$ & 16000 & 500 & 500 & 500 \\
\hline D C Water pump & * & 1000 & \multicolumn{3}{|c|}{ The salvage value of pump deducted during purchase of new pump after each 10 year } \\
\hline Paint 1lts(black) & $1 \mathrm{~L}$ & 125 & $*$ & $*$ & $*$ \\
\hline Fabrication/Cartridge charges & * & 2000 & $*$ & $*$ & * \\
\hline Capital cost (Rs) & & 42379 & 14435 & 21173 & 31031 \\
\hline
\end{tabular}

Operational, maintenance and pump replacement cost $=$ Rs. 1000/- per year.

Black painting, cleaning and glass replacement $=$ Rs. 3500/- every three year.

The life cycle conversion efficiency and annualized uniform cost (Rs./kWh) of the system are evaluated by considering the life time $(n)$ of the system as 10, 20 and 30 years and money is worth $10 \%$ per year. Result shows that the annualized uniform cost in Rs./kWh decreases and Life cycle conversion efficiency and Energy production factor increases with increase in life time of the system. Detailed results are shown in Tables 6 and 7.

Table 6. Energy Pay Back Time and Energy Production Factor on Annual Basis by Considering the Annual Thermal Energy and Exergy of the System

\begin{tabular}{|c||c|c|}
\hline & $\begin{array}{c}\text { Energy Pay Back } \\
\text { Time (EPBT) }\end{array}$ & $\begin{array}{c}\text { Energy Production } \\
\text { Factor (EPF) }\end{array}$ \\
\hline \hline Energy & 1.3 Years & 0.769 \\
\hline Exergy & 13.5 Years & 0.074 \\
\hline
\end{tabular}

\subsection{Carbon Credit Earned by PV/T Solar Water Heater}

\section{(a) Thermal Energy}

Total power produced per annum $=2720.1 \mathrm{kWh}$

$=2.72 \mathrm{MWh}$

If the unit cost of electricity is Rs. 5.5 then,

The cost of energy produced $=2720.1 \times 5.5=$ Rs. $14,960.55$ per annum

Average annual carbon emission reduction per MWh of electricity produced for the top 100 solar voltaic power plants, the data of electricity produced in MWh and emission reduction per annum for which are available. Which comes to 0.982 tons of carbon dioxide emission reduction per MWh of electricity produced [17]. However $40 \%$ is transmission and distribution losses and $20 \%$ loss is due to the inefficient electric equipments used. 
Table 7. Annualized Uniform Cost, Life Cycle Conversion Efficiency and Electricity Production Factor on Life Time Basis for $n=$ 10, 20 and 30 Years by Considering the Annual Thermal Energy and Exergy of the System

\begin{tabular}{|c|c|c|c|c|c|c|}
\hline \multirow{2}{*}{$\begin{array}{c}\text { No. of } \\
\text { Years }\end{array}$} & $\begin{array}{c}\text { Annualized } \\
\text { Uniform Cost } \\
\text { (Rs./kWh) }\end{array}$ & $\begin{array}{c}\text { Life Cycle } \\
\text { Conversion } \\
\text { Efficiency (LCCE) }\end{array}$ & $\begin{array}{c}\text { Energy } \\
\text { Production } \\
\text { Factor (EPF) }\end{array}$ & $\begin{array}{c}\text { Annualized } \\
\text { Uniform Cost } \\
\text { (Rs./kWh) }\end{array}$ & $\begin{array}{c}\text { Life Cycle } \\
\text { Conversion } \\
\text { Efficiency (LCCE) }\end{array}$ & $\begin{array}{c}\text { Energy } \\
\text { Production } \\
\text { Factor (EPF) }\end{array}$ \\
\hline \hline 10 Years & 2.94 & 0.317 & 7.65 & 30.4 & - & 0.741 \\
\hline 20 Years & 2.43 & 0.34 & 15.31 & 25.1 & 0.0114 & 1.48 \\
\hline 30 Years & 2.33 & 0.349 & 22.97 & 24.2 & 0.0194 & 2.22 \\
\hline
\end{tabular}

Total $=3,002,166$

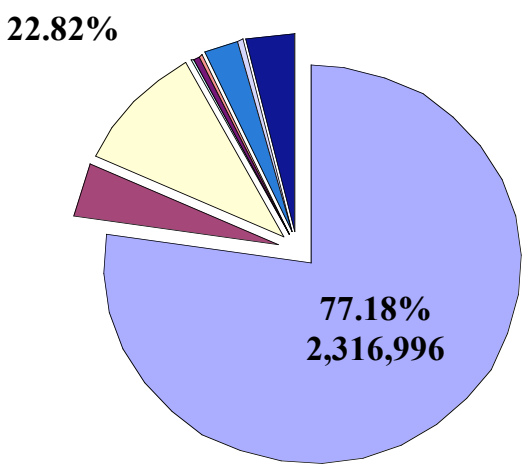

$\square$ Residence

Residence-cum-other use

$\square$ Shop, Office

口School, College, etc.

$\square$ Hotel, Lodge, Guest House, etc.

口 Hospital, Dispensary, etc.

Factory, Workshop, Workshed, etc.

$\square$ Place of worship

Fig. (5). Percentage variation of occupied census houses in Delhi. (Source: Census of India 2001). 0.2

Then, the total figure comes to be around $=0.982+0.4+$

$=1.58$ tons of $\mathrm{CO}_{2}$.

The carbon dioxide emission reduction $=2.72 \times 1.58$

$=4.3$ tons

If carbon dioxide emission reduction is at present being traded@@20/tons, then the carbon emission reduction by water heater comes to

$=4.3 \times 20 \times 53=$ Rs. 4558 per annum (where, $€ 1=$ Rs. 53)

\section{(b) Exergy}

Total power produced per annum $=263.3 \mathrm{kWh}$

$=0.263 \mathrm{MWh}$

If the unit cost of electricity is Rs. 5.5 then,

The cost of energy produced $=263.3 \times 5.5=$ Rs. $1,448.5$ per annum.

The carbon dioxide emission reduction $=0.263 \times 1.58$

$=0.4155$ tons

If carbon dioxide emission reduction is at present being traded@€ 20/tons, then the carbon emission reduction by water heater comes to

$=0.4155 \times 20 \times 53=$ Rs. 440.47 per annum

(where, $€ 1=$ Rs. 53) The Percentage variation of occu- pied census houses in Delhi [21] are shown in Fig. (5). The percentage of residence houses is $77.18 \%(2,316,996)$. If we assumed that the only $10 \%$ of the residence houses are installed PV/T hybrid water heater then the total carbon emission reduction by theses houses comes to

$=4558 \times 231,700=$ Rs. 105.6 corers per annum $($ in terms of thermal energy),

and

$=440.47 \times 231,700=$ Rs. 10.2 corers per annum (in terms of exergy).

\section{CONCLUSION}

This paper gives the detailed analysis of overall annual energy and exergy gain from hybrid PV/T solar water heating system. The annualized uniform cost $/ \mathrm{kWh}$ is higher in case of exergy when compared with cost $/ \mathrm{kWh}$ on the basis of thermal energy. If this type of system is installed only at $10 \%$ of the total residential houses in Delhi then the carbon credit earned by the system in terms of thermal energy is Rs. 105.6 cores and in terms of exergy is Rs. 10.2 cores annually. This system will increase the total carbon emission reduction and overall carbon credit earned as per the norms of Kyoto Protocol if it is integrated in a building.

\section{ABBREVIATIONS}

$$
\begin{array}{ll}
\mathrm{A} & =\text { Area, } \mathrm{m}^{2} \\
\mathrm{C} & =\text { Specific heat, } \mathrm{J} / \mathrm{kg} \mathrm{K}
\end{array}
$$


$\mathrm{F}^{\prime} \quad=$ Flat plate collector efficiency factor, dimensionless

$\mathrm{F}_{\mathrm{R}} \quad=$ Flow rate factor, dimensionless

$\mathrm{h}=$ Heat transfer coefficient, $\mathrm{W} / \mathrm{m}^{2}$

$\mathrm{PF}_{1}=$ Penalty factor first, dimensionless

$\mathrm{PF}_{2}=$ Penalty factor second, dimensionless

$\mathrm{I}(\mathrm{t})=$ Incident solar intensity, $\mathrm{W} / \mathrm{m}^{2}$

$\mathrm{K}=$ Thermal conductivity, $\mathrm{W} / \mathrm{m} \mathrm{K}$

$\dot{m}_{f} \quad=$ Rate of flow of water mass in collector, $\mathrm{kg} / \mathrm{sec}$

$\dot{m}_{w} \quad=$ Withdrawal flow rate of water from tank, $\mathrm{kg} / \mathrm{sec}$

$\mathrm{M}_{\mathrm{w}} \quad=$ Mass of water, $\mathrm{kg}$

$\dot{Q}_{u} \quad=$ Rate of useful energy transfer, $\mathrm{kW}$

$\mathrm{U}_{\mathrm{t} \mathrm{c}, \mathrm{a}}=$ An overall heat transfer coefficient from solar cell to ambient through glass cover, $\mathrm{W} / \mathrm{m}^{2} \mathrm{~K}$

$\mathrm{U}_{\mathrm{L} 1}=$ An overall heat transfer coefficient from blacken surface to ambient, $\mathrm{W} / \mathrm{m}^{2} \mathrm{~K}$

$\mathrm{V}=$ Air velocity, $\mathrm{m} / \mathrm{s}$

\section{Subscripts}

$$
\begin{array}{ll}
\mathrm{a} & =\text { Ambient } \\
\mathrm{c} & =\text { Solar cell } \\
c 1 & =\text { First collector } \\
c 2 & =\text { Second collector } \\
\text { eff } & =\text { Effective } \\
f_{i} & =\text { Inlet fluid } \\
f_{o} & =\text { Outgoing fluid } \\
g & =\text { Glass } \\
m & =\text { Module } \\
p & =\text { Plate } \\
t k & =\text { Water tank }
\end{array}
$$

\section{Greek Letters}

$\alpha \quad=$ Absorptivity

$(\alpha \tau)_{\text {eff }}=$ Product of Effective absorptivity and transmittivity

$\beta=$ Packing factor

$\eta_{i}=$ An instantaneous thermal efficiency

$\tau \quad=$ Transmitivity

\section{APPENDIX I}

Following Duffie and Beckman [18] and Tiwari [19], the flat plate collector efficiency is given by

$$
\begin{gathered}
F^{\prime}=\frac{1}{\frac{W \times U_{L}}{\Pi D h}+\frac{W}{D+(W-D) F}} \\
\text { where, } F=\frac{\tanh [m(W-D)] / 2}{[m(W-D)] / 2} \text { and } m=\sqrt{\frac{U_{L}}{K \delta}}
\end{gathered}
$$

Now, the flow rate factor $\left(F_{R}\right)$ given by

$F_{R}=\frac{\dot{m} C_{f}}{A_{c} U_{L} F^{\prime}}\left[1-\exp \left(-\frac{A_{c} U_{L} F^{\prime}}{\dot{m} C_{f}}\right)\right]$

In modeling equations, we use the following relations for defining the design parameters, which is shown in Table 2.

$$
(\alpha \tau)_{m, e f f}=P F_{1}(\alpha \tau)_{1, e f f}+(\alpha \tau)_{2, e f f}
$$

Here,

$$
(\alpha \tau)_{1, \text { eff }}=\left(\alpha_{c}-\eta_{c}\right) \beta_{c} \tau_{c} \text { and }(\alpha \tau)_{2, \text { eff }}=\alpha_{p}\left(1-\beta_{c}\right) \tau_{g}^{2}
$$

and the penalty factors due to glass cover of PV module $\left(\mathrm{PF}_{1}\right)$ and absorber below PV module $\left(P F_{2}\right)$ are defined as, $P F_{1}=\frac{h_{c, p}}{U_{t c, a}+h_{c, p}}$ and $P F_{2}=\frac{h_{p, f}}{U_{L 1}+h_{p, f}}$ $U_{t c, a}=5.7+3.8 \mathrm{~V}, U_{L 1}=\frac{U_{t c, a} \cdot h_{c, p}}{U_{t c, a}+h_{c, p}}$, $U_{L m}=\frac{U_{L 1} \cdot h_{p, f}}{U_{L 1}+h_{p, f}}$ $h_{c, p}=5.7+3.8 \mathrm{~V}, \mathrm{~V}=0 \mathrm{~m} / \mathrm{s}$

The values of $\mathrm{h}, \mathrm{h}_{\mathrm{p}, \mathrm{f}}, \alpha_{\mathrm{c}}, \tau_{\mathrm{c}}, \beta_{\mathrm{c}}, \eta_{\mathrm{c}}, \alpha_{\mathrm{b}}$ and $\tau_{\mathrm{g}}$ are taken from [12, 18, 19].

\section{REFERENCES}

[1] Jones AD and Underwood CP. A thermal model for photovoltaic systems. Solar Energy 2001; 70: 349-359.

[2] Zondag HA, de Vries DW, van Helden WGJ, van Zolingen RJC and van Steenhoven AA. The yield of different combined PVthermal collector designs. Solar Energy 2003; 74: 253-269.

[3] Chow TT. Performance analysis of photovoltaic-thermal collector by explicit dynamic model. Solar Energy 2003; 75: 143-152.

[4] Ji J, Lu JP, Chow TT, He W, Pei G. A sensitivity study of a hybrid photovoltaic/thermal water-heating system with natural circulation. Appl Energ 2007; 84: 222-237.

[5] Prakash J. Transient analysis of a photovoltaic-thermal solar collector for co- generation of electricity and hot air/water. Energ Conversion Mgmt 1994; 35: 967-972.

[6] Huang BJ, Lin TH, Hung WC and Sun FS. Performance evaluation of solar photovoltaic/thermal systems. Solar Energy 2001; 70: 443448.

[7] Tiwari A and Sodha MS. Performance evaluation of hybrid PV/thermal water/air heating system: A parametric study. Renew Energ 2006a; 31: 2460-2474.

[8] Tiwari A, Sodha MS, Chandra A, Joshi JC. Performance evaluation of photovoltaic thermal solar air collector for composite climate of India. Solar Energy Mater Solar Cells 2006; 90: 175-189.

[9] Zondag HA, de Vries DW, van Helden WGJ, van Zolingen RJC and van Steenhoven AA. The thermal and electrical yield of a PVthermal collector. Solar Energy 2002; 72: 113-128.

[10] Chow TT, He W, Ji J. Hybrid photovoltaic-thermosyphon water heating system for residential application. Solar Energy 2006; 80: 298-306.

[11] Kalogirou SA. Use of TRYNSYS for modeling and simulation of a hybrid PV- thermal solar system for Cyprus. Renewable Energy 2001; 23: 247- 260 .

[12] Tiwari A and Sodha MS. Performance evaluation of solar PV/T system: An experimental validation. Solar Energy 2006b; 80: 751759.

[13] Zondag HA. Flat-plate PV-Thermal collectors and systems A review. Renewable and Sustainable Energy Reviews 2007; Article in press. 
[14] Dincer I. The role of exergy in energy policy making. Energ Pol 2002; 30: 137-149.

[15] Raman V and Tiwari GN. Life cycle cost analysis of HPVT air collector under different Indian climatic conditions. Energ Pol 2008; 36: 603-611.

[16] Kalshian R. Energy versus emissions: The big challenge of the new millennium.ByInfo Change News \& Features 2006; (www.infocha ngeindia.org/agenda5_01.jsp).

[17] Anon. European Climate Exchange 2007; (www.europeanclimate exchange.com).
[18] Duffie JA and Beckman WA. Solar Engineering of Thermal Processes. John Wiley and Sons, New York: 1991.

[19] Tiwari GN. Solar Energy: Fundamentals, Design, Modeling and Applications. Narosa Publishing House, New Delhi: 2002.

[20] Petela R. Exergy of undiluted thermal radiation, Solar Energy 2003; 86: 241-247.

[21] Anon. Census of India - 2001, 2008; (http://www.censusindia. gov.in/Census_Data_2001/States_at_glance/State_Links/07_del.pdf).

Received: January 28, 2008

Revised: February 6, 2008

Accepted: February 10, 2008

(C) Dubey and Tiwari; Licensee Bentham Open.

This is an open access article distributed under the terms of the Creative Commons Attribution License (http://creativecommons.org/licenses/by/2.5/), which permits unrestrictive use, distribution, and reproduction in any medium, provided the original work is properly cited. 